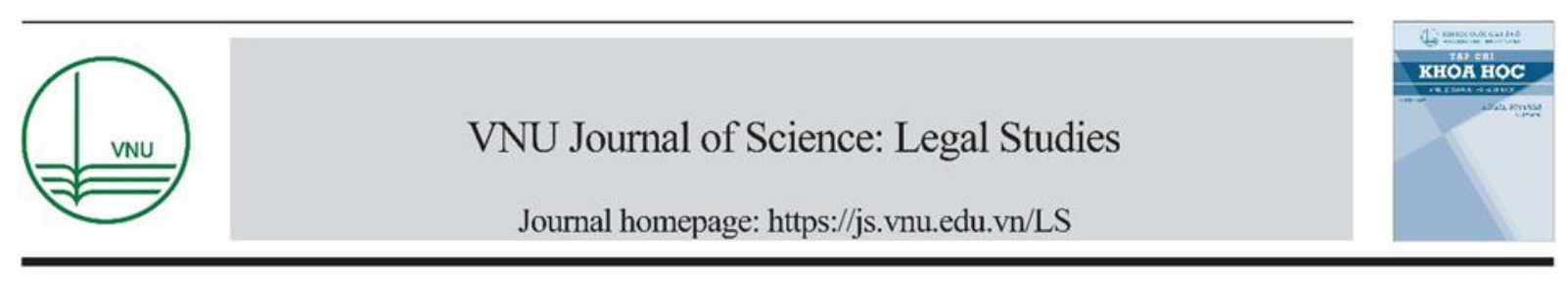

Original Article

\title{
Meiji Restoration: The Japanese Thought Revolution and Asian Perception
}

\author{
Do Duc Minh ${ }^{1, *}$, Vo Thi Hoa ${ }^{2}$ \\ ${ }^{1}$ Inspection and Legislation Department, Vietnam National University, Hanoi, \\ 144 Xuan Thuy, Cau Giay, Hanoi, Vietnam \\ ${ }^{2}$ Academy of Journalism and Communication, 36 Xuan Thuy, Cau Giay, Hanoi, Vietnam
}

Received 12 April 2019

Revised 25 May 2019; Accepted 05 June 2019

\begin{abstract}
The "Meiji Restoration", a series of reform and renovation events leading to tremendous changes in the Japanese social and political structure, has brought dramatic changes in the political, economic and social fields in Japan. The reform started from the change in perception and thinking: the Japanese bravely broke with the traditional views, traditional ideas and well-received thoughts; the progressive knowledge of mankind brought Japan to a strong integration and Japan achieved miracles in the national development. The achievements of the Meiji Restoration have established a solid framework and foundation for the development of modern Japan.
\end{abstract}

Keywords: Meiji Restoration, tradition, modernity, development.

\footnotetext{
* Corresponding author.

E-mail address: minhdd@vnu.edu.vn
}

_https://doi.org/10.25073/2588-1167/vnuls.4219 


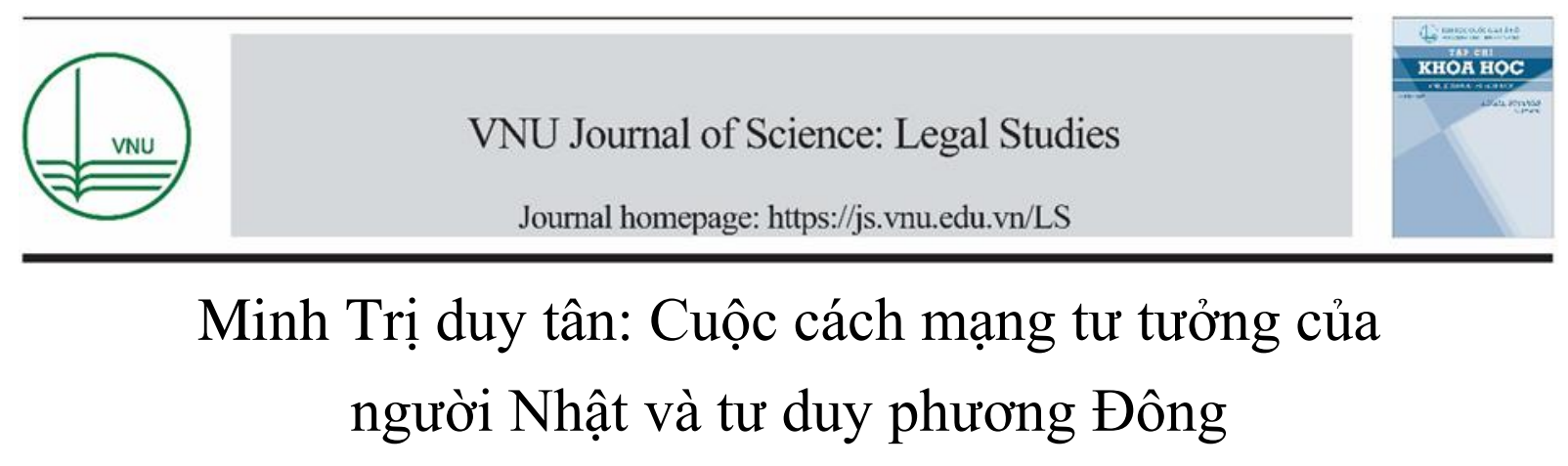

\author{
Đỗ Đức Minh ${ }^{1, *}$, Võ Thị Hoa ${ }^{2}$ \\ ${ }^{1}$ Ban Thanh tra và Pháp chế, Đại học Quốc gia Hà Nội, 144 Xuân Thủy, Cầu Giấy, Hà Nội, Việt Nam \\ ${ }^{2}$ Học viện Báo chí và Tuyên truyền. 36 Xuân Thủy, Cầu Giấy, Hà Nội, Việt Nam \\ Nhận ngày 12 tháng 04 năm 2019 \\ Chỉnh sửa ngày 25 tháng 5 năm 2019; Chấp nhận đăng ngày 05 tháng 6 năm 2019
}

\begin{abstract}
Tóm tắt: Là một chuỗi các sự kiện cải cách, cách tân dẫn đến những thay đổi to lớn trong cấu trúc xã hội và chính trị Nhật Bản; cuộc Cải cách "Minh Trị Duy Tân" đã mang đến những thay đổi mạnh mẽ trên các lĩnh vực chính trị, kinh tế và xã hội trong lòng nước Nhật. Bắt đầu từ sự thay đổi trong nhận thức và tư duy: người Nhật đã dũng cảm đoạn tuyệt với những quan điểm, tư tưởng truyền thống lạc hậu và đón nhận những tư tưởng, tri thức tiến bộ của nhân loại, đưa đất nước Nhật Bản bước vào thời kỳ hội nhập mạnh mẽ và giành được những kỳ tích trên con đường phát triển, xây dựng đất nước. Những thành tựu của công cuộc cải cách Minh Trị đã tạo lập khung khổ và nền móng vững chắc cho sự phát triển của đất nước Nhật Bản hiện đại.
\end{abstract}

Tù khóa: Cải cách Minh Trị, truyền thống, hiện đại, phát triển.

\section{Tư duy phương Đông và Nhật Bản}

\section{Một số vấn đề về tu duy phương Đông}

Tư duy phương Đông được nảy sinh trên nền tảng xã hội phương Đông với kết cấu kinh tế là những công xã nông thôn bảo thủ và hệ tư tưởng Nho giáo đề cao lễ nghĩa, coi nhẹ luật pháp, trọng tình hơn lí... chiếm địa vị thống trị

\footnotetext{
* Tác giả liên hệ.

Địa chỉ email: minhdd@vnu.edu.vn

https://doi.org/10.25073/2588-1167/vnuls.4219
}

tư tưởng trong suốt thời kỳ phong kiến và tạo ra truyền thống cai trị bằng đức 徳 với chủ nghĩa duy tình 唯 情 (còn phương Tây là pháp trị (Rule of law) và duy lí 唯 理). Triết học phương Tây ngả về tư duy duy lí, phân tích mổ xẻ còn phương Đông thì ngả về dùng trực giác. Tư duy phương Tây thiên về chủ biệt, tư duy phương Đông nghiêng về chủ toàn (GS. Trần Đình Hượu). Ý thức phương Đông thấm nhuần chất thơ hơn ý thức phương Tây, trừ trường hợp $\mathrm{Hy}$ Lạp. Văn minh phương Đông cổ xưa là văn minh làng xã, họ không đặt mục đích chinh phục thiên nhiên mà dựa vào thiên nhiên, gửi gắm tình cảm vào thiên nhiên để tồn tại và lập ra những hương ước nặng về tình để đối nhân 
xử thế. Trong khi đó, nền văn minh phương Tây với đặc trưng đô thị phát triển sớm, người phương Tây đã có ý thức cạnh tranh với thiên nhiên và siêu nhiên, chinh phục thiên nhiên và chinh phục thế giới để khẳng định sức mạnh của con người lí tính. Trong khi phương Tây với truyền thống văn hóa nổi bật luôn coi trọng chủ nghĩa cá nhân và quan niệm quyền lợi cá nhân thai nghén cùng với khái niệm công dân; văn hóa phương Đông nói chung luôn xem xét con người trong tổng thể các mối quan hệ xã hội, coi trọng những vai trò gia đình và dòng họ. Tư tưởng tôn trọng gốc gác nơi đất mẹ thiên nhiên (Ấn Độ) và cội nguồn huyết thống (Trung Quốc) của người phương Đông đã dẫn đến một ý thức thuần phục gần như tuyệt đối đối với tôn ti trật tự đã được thiết lập trong chính trị và tôn giáo. Trong thần thoại phương Đông, thế lực thần thánh được phát huy tuyệt đối quyền hành, tôn ti trật tự được tuân thủ nghiêm ngặt. Đạo Phật 佛 教 của phương Đông về cơ bản là nhất quán, thông suốt, hầu như không có những "kẻ phản nghịch"; nhưng ở phương Tây, đạo Cơ đốc luôn được sửa đổi, cải cách, thậm chí ly giáo. Người phương Tây mà từ tôn giáo tới các chế độ chính trị, kinh tế đều thấm nhuần chủ nghĩa cá nhân, dĩ nhiên không thích những học thuyết luân lí đã làm thỏa mãn tinh thần triết lí phương Đông trong suốt chiều dài lịch sử. Đề cao sức mạnh của thiên nhiên và siêu nhiên, người phương Đông quan niệm con người phụ thuộc vào thiên nhiên và thế giới siêu nhiên. Phải chăng mối quan hệ tình cảm có phần huyền bí giữa con người với thiên nhiên và với thế giới siêu nhiên là lí do chính tạo ra kiểu tư duy này?

Nghiên cứu lịch sử tư tưởng (tư duy) phương Đông, chúng ta thấy phần nổi trội nhất mang tính chi phối là tư tưởng Trung Quốc ${ }^{1}$; vì vậy, nghiên cứu lịch sử tư tưởng của quốc gia này cho thấy những yếu tố tiêu biểu và qua đó

\footnotetext{
${ }^{1}$ Cùng với Ấn Độ và Hy Lạp, Trung Hoa là một trong ba cái nôi của nền văn minh lớn nhất nhân loại còn tồn tại tới ngày nay. Trong các nôi ấy, văn minh Ẩn Độ và Trung Quốc được phát triển liên tục trong tiến trình lịch sử.
}

có thể sáng tỏ đặc trưng chung của các tư tưởng chính trị phương Đông. Đối với vùng Viễn Đông, Trung Quốc có vai trò truyền thống giống như vai trò của đế chế La Mã ở châu Âu nghĩa là nguồn cảm hứng thường trực đối với các vấn đề về chính trị, văn hóa, tôn giáo, triết học và khoa học. Đây cũng là một nền văn hóa trong một thời kỳ nhất định đã có tác dụng trong nhiều mặt đối với phương Đông và lịch sử loài người, như: kỹ thuật sản xuất, ảnh hưởng của tổ chức xã hội, tư tưởng đạo đức...

Đời sống chính trị Trung Quốc và một số nước Đông Á chịu ảnh hưởng lớn bởi các dòng tư tưởng chính trị: Nho gia 儒家 (hay Khổng giáo 孔 教), Pháp gia 法 家 và Đạo gia 道 家. Đặc biệt, "phương Đông nặng về tư tưởng Nho giáo còn phương Tây thiên về chủ nghĩa văn minh" [3, tr.344]. Đường lối Đức trị 德 治 của Khổng Tư đã thống trị trong xã họi phong kiến Á Đông hàng nghìn năm lịch sử đã ảnh huởng sâu sắc đến kết cấu văn hóa, đặc tính tâm lí và luân lí của nhân dân Trung Quốc, đồng thời tạo nên một truyền thống lớn của văn hóa khu vục. Là một học thuyết coi trọng huyết thống, chuộng gốc, nhớ nguồn, đề cao trung-hiếu, tôn ti trật tự; Nho giáo giúp các xã hội này có tính tổ chức cao, duy trì trật tự xã hội, gìn giữ các tiêu chuẩn đạo đức của xã hội ở một mức khá cao, xã hội văn minh và ổn định lâu dài. Nho giáo tiến hành tất cả những điều đó không phải bằng vũ lực mà bằng chủ trương giáo dục toàn diện từ vua quan đến nhân dân để mỗi người đều tự giác thực hiện tùy theo vai trò của mình ( 自天子以至於庶人, 壹是皆以修身為 本; 君 君, 臣臣, 父父, 子子 - Tự thiên tử dĩ chí ư thứ nhân, nhất thị giai dĩ tu thân vi bản [1, tr.1042]; "Quân quân, thần thần, phụ phụ, tử tử" - Vua ra vua, bề tôi ra bề tôi, cha ra cha, con ra con [1, tr.290] và đó cũng là lí do tại sao những nước sùng đạo Nho đều rất coi trọng giáo dục.

Là tư tưởng chính thống và chiếm địa vị chủ yếu trong lịch sử Trung Quốc, Nho giáo đã góp phần xây dựng một dạng thức đặc trưng của cấu hình tư tưởng và cấu hình tư duy phương Đông. Từ đời Hán, chủ trương độc tôn 
Nho đã bóp méo Nho giáo nguyên thủy đến cực đoan để phục vụ cho yêu cầu chính trị độc tài chuyên chế: quân xử thần tử, thần bất tử bất trung; phu xư tư vong, tử bất vong bất hiếu 君 處臣死臣不死不忠, 父處子忘子不忘 不 孝. Tính chất chính trị độc tài, thống soái, đứng trên và chi phối mọi hình thái ý thức xã hội khác (kể cả pháp luật) là một điển hình của phương Đông. Ánh hào quang thần bi của vuoong quyền, tu tưởng trung quân tuyệt đối của đạo Nho và sụ trùng phạt tàn bạo của pháp luật là đảm bảo vũng chắc cho vuoong vị và vuơng quyền, mang bản sắc văn hóa - pháp lí phương Đông. Sự khắt khe của pháp luật phong kiến cũng như lệ tục của làng xã cổ truyền (do ảnh hưởng sâu sắc của tư tưởng Nho giáo - nhất là Tống Nho 宋 儒) nên vị trí và vai trò của người phụ nữ trong xã hội rất mờ nhạt, bị đối xử bất bình đẳng so với nam giới. Các quan niệm trọng nam khinh nũ 重男輕女, đạo tam tòng 三 從, thất xuất 七出, nga tư sư tiểu, thất tiết $s u ̛$ đại 饿死事小失节事 大 $^{2}$ (Trình thị di thư) đầy bất công đã buộc chặt người phụ nữ vào những khuôn phép khắc nghiệt vô hình và chịu nhiều bất hạnh. Đặc biệt, từ khi chế độ phong kiến tập quyền thành lập thì Khổng học trở nên độc tôn thì ngày càng quay về xu hướng bảo thủ, lạc hậu, xa rời thực tế. Dưới chế độ quân chủ chuyên chế phương Đông, yếu tố dân

\footnotetext{
${ }^{2}$ Trọng nam khinh nũ là tư tưởng đề cao vai trò, vị trí của người nam giới, xem thường, hạ thấp vai trò của phụ nữ, tiêu biểu là quan niệm thập nũ viết vô, nhất nam viết hũu 十女日无，一男曰有 (Sinh được một con trai mới được gọi là có con, sinh được mười con gái cũng coi như không có con). Tam tòng là 3 nguyên tắc của giáo lí phong kiến: tại gia tòng phụ, xuất giá tòng phu, phu tử tòng tử 在 家 從父, 出嫁從夫, 夫死從子 bắt người đàn bà phải tuân thủ là khi ở nhà phải theo cha, khi lấy chồng phải theo chồng, khi chồng chết phải theo con trai. Thất xuất (7 lí do được bỏ vợ): Luật pháp phong kiến cho phép người chồng được bỏ vợ khi họ phạm vào một trong những 7 điều sau đây: Không có con, Ghen tuông, Ác tật (bị bệnh nan y), Dâm ô (không đoan chính), Không kính trọng bố mẹ chồng, Đa hôn (lắm điều), Trộm cắp. $N g a$ tư sư tiểu, thất tiết sụ đại - Nghĩa là: "Đói chết là việc nhỏ, thất tiết mới là việc cực lớn” (Trình thị di thư).
}

chủ, tư tưởng tự do hầu như không được biểu hiện.

\section{Nhật Bản: Vài nét về tư tưởng truyền thống}

Là một quần đảo cô lập nằm nhỏ nhoi như một dấu ngoặc lửng ở rìa phía đông của khu vực giao lưu giữa A - Âu rộng lớn, tương đối biệt lập với các quốc gia khác tại châu Á trong nhiều thế kỉ cho tới thời kỳ mở cửa (năm 1868), nên Nhật Bản ${ }^{3}$ có các nét riêng về phong tục, tập quán, chính trị, kinh tế và văn hóa. Việc chuyển từ chế độ nô lệ sang chế độ phong kiến cùng với sự thay đổi của các quan hệ mang tính giai cấp cũng trải qua một thời kỳ lâu dài và phụ thuộc vào những bước tiến từ từ. Pháp luật cồ đại của Nhật chính là sự kết hợp của đạo Saman - một tôn giáo mang tính sơ khai. Từ thế kỉ VI-VIII, trên quê hương Núi Phú Sĩ, Hoa Anh đào, Thần đạo (神 道/Shintō) và Sumo, một nhà nước tập quyền được thành lập và đóng đô ở Asuka (gần thành phố Nara ngày nay), tên nước từ Đại Hòa (大 和/Yamato) đổi thành Nhật Bản. "Năm 646, cuộc cách tân Đại Hóa (大 化改 新/Taika), thời kỳ này, Nhật Bản còn tàn dư xã hội thị tộc, lạc hậu hơn Trung Quốc và người Nhật Bản đã học Trung Quốc. Cũng chính thời kỳ này, Nhật Bản khẳng định thời kỳ phong kiến, xây dựng nhà nước trung ương tập quyền" [2, tr.92]; Hoàng đế được gọi là Thiên Hoàng (天 皇/Tenno), có uy quyền lớn ${ }^{4}$. Trong quá trình xác lập nhà nước phong

\footnotetext{
${ }^{3}$ Nhật Bản 日本, Nihon), theo chữ Hán có nghĩa là "Gốc của Mặt Trời" hay "Đất nước Mặt Trời mọc". Năm 670, đời vua Đuờng Cao Tông 唐 高 宗, Nhật Bản gửi một sứ bộ đến chúc mừng triều đình nhà Đường nhân dịp vừa bình định Triều Tiên và từ đó được đổi tên là Nhạt Bản. Theo sử sách, các học giả Triều Tiên đã giới thiệu kiến thức và kỹ thuật của Trung Quốc, chữ Hán và những tác phẩm kinh điển (như Luận ngũ 论 语) vào Nhật Bản. Năm 554, một vương quốc Triều Tiên tên là Bách Tế đã gửi bác sĩ, chuyên gia dược thảo, làm lịch và thầy tu đến Nhật Bản.

${ }^{4}$ Hiếu Đức Thiên hoàng 孝徳天皇/Karu (Ame Yorozu Toyohi no Sumera Mikoto; 645- 654) tiến hành cải cách để xác lập quyền thống trị của phương thức sản xuất phong kiến Nhật Bản. Nội dung chính của cải cách là thực hành chế độ ban điền 頒田制, kê nhân khẩu mà ban ruộng và đổi mới quan chế. Với chế độ này, giai cấp thống trị
} 
kiến, các nhân tố ngoại lai đóng một vai trò khá quan trọng và ảnh hưởng của nền pháp luật, các học thuyết chính trị Trung Quốc đối với Nhật Bản rất sâu sắc. Đồng thời, từ quê hương Ấn Độ, Đạo Phật được truyền sang Nhật (qua Trung Quốc) với tổ chức tôn ti và có tính chất tập trung, là một thứ khuôn mẫu cho nhà nước phong kiến Nhật Bản mô phỏng. Đó là "một con chim lớn kỳ diệu, bay qua đại dương trên đôi cánh mạnh mẽ, mang tới cho Nhật Bản tất cả những nhân tố của một đời sống mới - một nền đạo đức mới, kiến thức về tất cả các lĩnh vực: văn học, nghệ thuật, nghề nghiệp, và các tư tưởng siêu hình tinh tế vốn chưa từng xuất hiện trong truyền thống bản địa" [4, tr.75]. Dưới tác động của mô hình cai trị nhà Đường, Nhật Bản cố gắng xây dựng một chính quyền Trung ương tập quyền dựa trên một hệ thống pháp luật hoàn bị đứng đầu là Thiên Hoàng. Đến thời kỳ Nara (710 - 794), nền văn hóa đạt tới mức cao nhờ kết hợp các yếu tố Trung Hoa và Nhật Bản. Để xác lập quyền lực mang tính chuyên chế của Thiên Hoàng thì một hình thức pháp luật đã được xây dựng theo kiểu luật nhà Tấn (晉 朝, 266-420) và nhà Đuoòng (唐 朝, 618-907) ở Trung Quốc. Các Bộ luật hình sự phong kiến Luật lệnh (律 令/Ritsuryo) được ban hành vào đầu TK VIII "là bản sao hoàn toàn của Bộ luật hình sự nhà Đường”. Bộ luật hình sự năm 1870 cũng lấy mẫu các bản hình pháp của nhà Minh và nhà Thanh, đồng thời thể chế hóa luật Yedo của Mạc phủ. Nhìn chung, Nhật Bản chưa xuất hiện một nền pháp luật độc lập mà còn chịu ảnh hưởng khá lớn của pháp luật phong kiến Trung Hoa (chủ yếu là hệ tư tưởng Nho gia và pháp giatừ thời cổ đại kéo dài suốt thời kỳ trung đại và cận đại. "Ở Nhật Bản, rõ ràng chịu ảnh hưởng rất nhiều của các Bộ luật vay mượn của Trung Quốc, những Bộ luật này đã mục nát và biến đồi qua năm thế kỉ sử

duy trì các lãnh địa có tính chất chức vụ hay đẳng cấp, nông dân được những khoảnh đất phân theo đầu người và phải nộp tô thóc, sản phẩm thủ công nghiệp gia đình và làm nghĩa vụ lao dịch cho nhà nước. Như vậy, "chế độ ban điền" nhằm cải biến chế độ thuế 稅 cũ theo chế độ tô 租, dung 庸, điệu 調 của nhà Đường. dụng ở Nhật Bản, vẫn để lại một di sản được các tài liệu viết kính trọng và các chuyên gia dựa vào" $[4$, tr.23]. Cũng như luật pháp phong kiến Trung Hoa và các nước trong khu vực, luật pháp Nhật Bản thời kỳ này thể hiện công khai sự phân biệt đẳng cấp khắc nghiệt. Pháp luật cũng không có sự phân định rạch ròi giữa tội hình sự, dân sự và việc không chấp hành nghĩa vụ thông thường (ví dụ: kẻ không trả được nợ cũng bị xử hình sự như người thường phạm tội trộm cắp). Việc ban hành pháp luật nhẳm để bảo vệ và củng cố những đặc quyền của giai cấp phong kiến ${ }^{5}$. Tuy nhiên, do không có bệ đỡ vững chắc của một thể chế chính trị tập quyền cao và không phải là một xã hội thuần nông nghiệp, nên mặc dù được chính quyền Edo tôn vinh nhưng khi thâm nhập vào xã hội Nhật Bản, thì nhiều giá trị của hệ tư tưởng Nho giáo đã bị biến đổi để thích ứng với môi trường chính trị mới. Người Nhật đã tiếp nhận Nho giáo theo cách thức riêng của mình và kết quả là Nho giáo không thể trở thành hệ tư tưởng chính thống trên bình diện quốc gia và giữ vai trò độc tôn ở Nhật Bản. Vì vậy, mặc dù cố thâu tóm quyền lực vào chính quyền trung ương, củng cố chế độ độc tài chuyên chế nhưng nhà nước Nhật Bản vẫn không ngăn cản được khuynh hướng phân quyền cát cứ ${ }^{6}$. Thay vào đó, hình thức chuyên chính quân phiệt được xem như một nét đặc trưng trong quá trình phát triển của nhà nước phong kiến Nhật Bản.

Ngày nay, đa số các học giả đều cho rằng Nho giáo bắt đầu được truyền bá vào Nhật Bản

\footnotetext{
${ }^{5}$ Bộ luật Bách pháp 百 法 (một trăm đạo luật) của Nhật Bản bao gồm các quy phạm về luật dân sự, hình sự và tố tụng.., song chưa chia thành từng ngành luật cụ thể. Thậm chí, trong thời kỳ cách mạng tư sản (Minh Trị duy tân), Bộ luật hình sự năm 1870 (năm Minh Trị thứ ba) và những bổ sung về sau cũng lấy mẫu hình pháp nhà Minh, Thanh (Trung Quốc), thể chế hóa luật Edô của Mạc phủ và không hề mang bóng dáng của luật tư sản.

${ }^{6}$ Từ TK XV - XVI, khuynh hướng phân quyền ngày càng rõ nhưng đồng thời diễn ra xu thế phát triển tập quyền. Sau này, Mạc phủ Tokugawa Ieyasu (Mạc phủ Edo, 1600 1868) đã có nhiều nỗ lực hướng đến xây dựng một chính quyền trung ương tập quyền mạnh, song không xác lập được quyền lực tuyệt đối và ngăn chặn được khuynh hướng phân quyền.
} 
qua Triều Tiên vào khoảng trước thế kỉ thứ $\mathrm{V}$ qua con đường giao thương buôn bán và qua những người Hàn Quốc di cư sang Nhật Bản. Nhưng phải đến nửa đầu thế kỉ VI, giai cấp quý tộc Nhật Bản mới chính thức chịu ảnh hưởng của tư tưởng Nho giáo. Ban đầu, do phương thức học tập dựa trên sự truyền thụ cá nhân nên việc học chỉ phổ biến cho hoàng gia và một số người trong triều đình. Mặt khác, do chú trọng đến cái học huấn hỗ 訓 詁 學 (nghiên cứu nghĩa chữ cổ, chú giải ý nghĩa kinh điển) nên lúc này Nho giáo chỉ phù hợp với người có học vấn cao và không phổ biến nhanh chóng như Phật giáo mà chỉ hạn chế trong một bộ phận nhất định của giới thượng lưu. Thái tủ Sotoku 聖徳太子 (574 - 622) đã dùng lí tưởng Nho học để xây dựng pháp luật và tư tưởng Nho giáo được thể hiện đầu tiên trong "Luật 17 điều” 憲 法 十七 条 (Kenpô jùshichi jô) do nhà cách cách vĩ đại Shôtoku Taishi/Thánh Đức Thái Tử 聖徳太子 (574 - 622) soạn thảo công bố năm 604 đặt tư tưởng trung quân lên hàng đầu "nước không thể có hai vua, dân không thể có hai chủ" ${ }^{7}$. Du nhập vào Nhật Bản, trong những buổi đầu Khổng giáo không phổ biến nhanh như Phật giáo mà chỉ hạn chế trong một bộ phận thuộc giới thượng lưu. Trong không gian của xã hội Nhật Bản và biệt lập, Nho giáo Trung Hoa đã không thể lan truyền mà không bị biến tướng. "Ngay tù đầu người Nhật ở múc độ nào đấy đã lĩnh hội các luận thuyết theo cách riêng của mình và vận dụng nhũng luận giải khác về chúng. Cuộc cách mạng tôn giáo đã diễn ra một cách mau chóng, và có lẽ là vố thức, ngay trên boong của các con tàu đến tì̀ Trung Quốc và Triều Tiên hay trên các bãi tắm tại các bờ biển Nhật Bản" [5]. Không chỉ tiếp thu Nho giáo từ Triều Tiên sang, triều đình Nhật Bản còn cử các đoàn sứ giả sang Trung Quốc giao lưu, học tập và tiếp thu Nho giáo qua thế giới quan của mình về truyền bá lại cho dân chúng. Sau cuộc cách tân Đại Hóa, Nhật Bản mô phỏng theo chế độ luật lệnh của nhà Tuỳ,

\footnotetext{
${ }^{7}$ Nho giáo quan niệm Trung thần bất sự nhị quân 忠 臣 不事二君. Ỏ̉ Nhật Bản, chữ Trung 忠 là đức mục được đề cao nhất.
}

Đường thì vị trí của Nho giáo trở nên quan trọng nhưng vẫn có sự hài hòa với Phật giáo (thời kỳ Thái tử Sotoku). Từ cuộc cải cách Taika đến đầu thế kỉ VIII, hệ thống chính trị Nhật Bản mang màu sắc đơn thuần Khổng giáo gần như một bản sao của hệ thống chính quyền nhà Đường cho dù có một số điều chỉnh cho phù hợp với điều kiện, hoàn cảnh thực tế của Nhật Bản [6]. Từ đó, Khổng giáo trở thành bệ đỡ cho tư tưởng chính trị quốc gia và là kiến thức bắt buộc đối với những người tham chính..

Tuy nhiên, vào giai đoạn phát triển điển hình của chế độ phong kiến Nhật Bản, Khổng giáo lại có phần chìm lắng, nhường lại địa vị cao nhất cho Phật giáo Thiền tông. Đến thời Nara và giai đoạn đầu của thời Heian (平安 時 代, Heian-jidai: Bình An thời đại, 794 - 1185), Nho học phát triển mạnh mẽ trong tầng lớp quí tộc và tăng sĩ nhưng Khổng giáo vẫn còn nằm trong cấu trúc Tam giáo với sự ưu trội của Phật giáo. Sự phổ biến của Khổng giáo lúc này hầu như chỉ bó hẹp trong phạm vi cơ quan giáo dục cao nhất là Đại học liêu 大 學 僚 cùng một vài trường tư. Đến hậu kỳ trung đại là thời kỳ suy thoái của chế độ phong kiến (thời kỳ Edo, TK XVII -1868$)^{8}$ và nảy sinh những mầm mống tư bản chủ nghĩa $(\mathrm{TBCN})$ cùng với sự lên ngôi của tầng lớp thị dân ở các đô thị, Nho giáo đã thay thế cho Phật giáo trong đời sống và đẩy Phật giáo xuống vị trí khiêm tốn hơn. Học phái Chu Tử (Chu Hi 朱喜, 1130-1200) được Mạc phủ khuyến khích và trở thành Nho giáo chính thống của nhà nước (gọi là Quan Nho phái 官 儒 派). “Từ năm 1790 thuyết Chu Tử, đại biểu cho Nho học, được coi là triết học chính thống trong xã hội phong kiến Nhật Bản. Để duy trì hữu hiệu xã hội phong kiến về mặt luân lí, chính quyền phong kiến Mạc phủ cấm những học thuyết khác với thuyết Chu Tử" $[15$,

\footnotetext{
${ }^{8}$ Thời kỳ Edo 江 戸 時 代/ Edo-jidai? còn gọi là Giang Hộ thời đại, thời kỳ Tokugawa, Đúc Xuyên thời đại 徳 川 時 代/Tokugawa-jidai, Đúc Xuyên Mac phủ 徳川幕府Tokugawa Bakufu; chính quyền Mạc phủ ở Nhật Bản do Tokugawa Ieyasu thành lập và trị vì trong thời kỳ từ năm 1603 cho đến năm 1868 bởi các Chinh di Đại tướng quân nhà Tokugawa.
} 
tr.127]. Khổng học ngày càng trở nên nghiêm khắc hơn để chống lại dị học 异 學 - trào lưu tôn giáo từ phương Tây mang đến. Chuyển sang thời kỳ cận đại (1868-1945), Thiên hoàng Minh Trị (明 治 天 皇, Meiji-tennō) lên ngôi tuyên bố bắt đầu công cuộc duy tân để đưa nước Nhật đuổi kịp các nước phương Tây. Lúc này, những nhà duy tân tự do thấy được hạn chế của Nho giáo (nhất là Tống Nho) đối với công cuộc cải cách đã khuyến khích thực học, tinh thần tự cường ${ }^{9}$. Trong khi đó, triều đình và những trí thức quý tộc tuy thấy được những bất cập của Nho giáo nhưng vẫn muốn sử dụng Nho giáo làm công cụ giáo dục đạo đức, lòng trung thành với Thiên hoàng, xây dựng đất nước Nhật Bản theo chủ trương phú quốc cuoòng binh (富国強 兵/fukoku kyohei - nước giàu binh mạnh). Có thể thấy rằng: do đặc thù (sự biệt lập tương đối) về địa lí, sự thuần nhất về văn hóa của Nhật Bản và không bị nước ngoài (Trung Hoa) đô hộ nên khác với nhiều nước Đông Á trong khu vực, những ảnh hưởng văn hóa từ Trung Hoa truyền vào Nhật Bản không phải bằng con đường cưỡng bức mà bằng chính thái độ tự nguyện và chủ động lựa chọn tiếp thu ${ }^{10}$. Những điều kiện đó đã giúp Nhật Bản có thể duy trì sự

\footnotetext{
$\overline{9}$ Tiêu biểu cho khuynh hướng này là Nhóm Minh Lục Xã/ 明六社/ Meirokusha và Fukuzawa Yukichi/福 沢 諭 吉 nhà tư tưởng của phong trào duy tân Nhật Bản đã viết Khuyến hoc 学 問/のす寸女 để đưa ra tư tưởng giáo dục mới, viết Thoát Á luận 脱 亜 論khuyến khích Nhật Bản thoát khỏi một châu Á chậm phát triển và phải chịu ô nhục trước các nước đế quốc phương Tây.

${ }^{10}$ Theo Cổ sư ký 古事記 và Nhật Bản thu kỉ 日本書紀, hai bộ sử tối cổ của Nhật Bản (TK VIII) thì vào TK V, thời Úng Thần thiên hoàng 応神天皇/Ojintennnô, vua nước Bách Té là Tiêu Cổ 肖古/Shôko phái sứ giả $A$ Trực $K y$ 阿 直 岐/Achigi dâng hai con ngựa tốt. Nhận thấy Achigi đối đáp nhanh nhẹn, tỏ ra thông tuệ, Thiên Hoàng hỏi: "Trong nước Bách Tế có ai giỏi hơn ngươi không?". Achigi trả lời rằng có người tên là Vương Nhân. Triều đình Nhật Bản bèn cho mời Vương Nhân sang. Vua nước Bách Tế bèn dâng Vương Nhân cùng với 10 quyển Luận $n g \tilde{u}$ 論 語 và 01 quyển Thiên tụ văn 千字文. Sau đó, Vương Nhân dạy cho Thái tủ Thố Đạo Trĩ Lang Tủ 菟道 稚郎 $/ \mathrm{Uji}$ no Wakiiratsuko kinh điển Nho gia (http://khoavanhoc-ngonngu.edu.vn/).
}

ổn định, tính bền vững xã hội và chủ động tiếp thu những luồng tư tưởng từ bên ngoài vào.

\section{Cải cách Minh Trị}

\section{Trung Quốc và Phuơng Tây: sụ lựa chọn của người Nhật giữa hai dòng nước}

Trong lịch sử, Trung Quốc từng được xem là cội nguồn trí tuệ của Nhật Bản: Kyoto (được thành lập từ $\mathrm{TK}$ VIII)- thủ phủ chính trị của Nhật Bản trong suốt một ngàn năm, là một bản sao hoàn hảo của kinh đô Trương $A n$ 長 安 triều nhà Đường. Nhiều thi phẩm lớn của Nhật Bản được viết tại Trung Quốc. Đối với nam giới, hoc 學 đồng nghĩa với việc học ở Trung Quốc. Hầu như tất cả những giá trị văn hóa của người Nhật đều xuất nguồn từ Trung Quốc, từ truyền thống trồng lúa nước, chữ viết, các quan điểm Khổng giáo về trật tự quân thần và gia đình, cho đến các kỹ thuật sử dụng đồng và sắt. Dấu ấn của Khổng giáo cũng thể hiện rõ nét trong trật tự xã hội của Nhật Bản: Lịch sử Nhật Bản đã khẳng định thần quyền của Thiền Hoàng là "Thiên mệnh Trời trao" (天 命) bất di bất dịch từ cổ chí kim và là quyền lực tuyệt đối. Là người nắm giữ quyền lực tối cao và quyết định mọi việc của đất nước luôn được đề cao, Thiên Hoàng được xem là con cháu của các vị thần và được suy tôn ở khắp mọi nơi; tất cả ý chí tinh thần của dân chúng đều nhằm phục vụ Thiên Hoàng. Với vị thế của mình, Thiên Hoàng là người có quyền lập pháp, hành pháp và tư pháp (song để thực hiện điều này còn phụ thuộc vào từng triều đại mà các Thiên Hoàng là đại diện). Ảnh hưởng của Nho giáo đến trật tự, quan hệ xã hội Nhật Bản còn biểu hiện ở sự phân chia các giai cấp tầng lớp khá rạch ròi. Nhật Bản cũng được cho là đất nước rất coi trọng con người và đạo đức, tính kỉ luật cao và sự cố kết cộng đồng chặt chẽ, có hệ thống kính $n g \tilde{u}$ 警 護, khiêm nhường ngũ 尊 敬 語 khá phức tạp ${ }^{11}$ (những yếu tố này được xem như

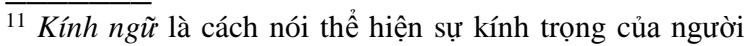
nói với người nghe, hoặc người được nói tới. Việc dùng
} 
chìa khóa mở ra sự thành công và phát triển, giúp đất nước Hoa Anh đào vượt qua những thiên tai, khó khăn trong lịch sử). Những tư tưởng tu thân 修 身, chính danh 正名, tam cưong ngũ thường 三綱五常 là những nền tảng để tạo lập trật tự xã hội, giữ gìn mối quan hệ giữa người với người; góp phần quan trọng vào việc duy trì một xã hội thịnh trị, ổn định và phát triển. Thông qua giáo dục, chính quyền muốn khẳng định địa vị của từng giai tầng, cá nhân trong trật tự xã hội. Ở Nhật Bản, tư tưởng Nho giáo có ý nghĩa tích cực làm cho con người ý thức được trách nhiệm, nghĩa vụ của mình trong các mối quan hệ xã hội; là nhân tố quan trọng làm cho xã hội ổn định trật tự, có trên có dưới, từ đó tu thân để ngày một tốt hơn. Bên cạnh những nét văn hóa đặc sắc, chế độ giáo dục ở Nhật Bản thời kỳ Tokugawa cũng chịu ảnh hưởng nhiều mặt của nền văn minh Trung Hoa mà đặc điểm khá nổi bật là sư phân biệt đẳng cấp rất rõ rệt. Tuy nhiên, ảnh hưởng của tư tưởng Nho giáo cũng có những hạn chế, tiêu cực như: tư tưởng tuyệt đối hóa vai trò của vua, hoàng đế, thiên hoàng, từ đó tạo ra tư tưởng bảo thủ, độc quyền độc đoán, tính giáo điều trở thành nếp trong suy nghĩ của người Nhật. Những tư tưởng khắt khe về lễ 禮, nghĩa 義, trung, hiếu 孝 đôi khi cũng là sợi dây bó buộc, kìm hãm sự triển của con người. Ngoài ra, một trong những vấn đề xã hội mà Nhật Bản chịu ảnh hưởng khá sâu sắc từ Nho giáo là vai trò, vị

kính ngữ tùy thuộc vào 3 yếu tố. (i) Khi người nói ở vị trí thấp hơn về mặt tuổi tác hoặc địa vị xã hội thì dùng kính ngữ để biểu thị sự kính trọng đối với người nghe có vị trí, tuổi tác cao hơn mình. (ii) Dùng trong trường hợp người nói có quan hệ không thân lắm với người nghe, như khi gặp nhau lần đầu...(iiu) quan hệjち- uchi (bên trong), そ と- soto (bên ngoài) cũng cần dùng tới kính ngữ. Khái niệmうち- uchi chỉ những người thuộc cùng nhóm với mình như gia đình, công ty, nhà trường,...còn khái niệm そと - soto chỉ những người ngoài nhóm với mình. Khi người nói nói với người bên ngoài về người trong cùng nhóm của mình thì người trong nhóm đó sẽ có vị trí tương đương với người nói. Vì thế cho dù người bên trong có vị trí cao hơn nhưng khi nói với người ngoài thì người nói cũng sẽ không dùng kính ngữ như khi nói với người đó. Khiêm nhường ngũ cũng là cách thể hiện sự tôn kính đối với người nghe hoặc người được nói tới. trí của người phụ nữ: Tuy không chịu quá nhiều khuôn khổ hà khắc của Nho giáo phong kiến như phụ nữ Trung Quốc (quê hương của Nho giáo) nhưng so với nam giới, phụ nữ Nhật Bản vẫn phải chịu nhiều thiệt thòi và có sự phân biệt nhất định ${ }^{12}$. Bên cạnh những ảnh hưởng của tập tục truyền thống khác về tín ngưỡng, tôn giáo (như quan niệm về sự ô uế -kegare), những tư tưởng phân biệt quan hệ trong thang bậc đẳng cấp phong kiến, giới tính, trọng nam khinh nữ của Nho giáo đã tạo ra hố sâu ngăn cách, cản trở sự phát triển xã hội.

Từ đầu TK $X$ đến TK XIX (tương ứng với thời kỳ Tống-Nguyên-Minh-Thanh), chế độ phong kiến Trung Quốc từ phục hưng chuyển sang giai đoạn suy vong. Cũng trong giai đoạn này, sự uy nghi của nền văn minh Trung Quốc dần dần suy yếu (nhất là từ năm 1644 khi triều Minh sụp đổ và nhà Hán bị nước ngoài kiểm soát ${ }^{13}$ ). Đặc biệt, sang thế kỉ XIX, nội bộ Trung Quốc thối nát rõ rệt: vua chúa chỉ lo hưởng thụ, quan lại hủ bại bất tài, quân đội cũng chỉ là quan liêu có đeo kiếm. Kinh tế sa sút, nội bộ mâu thuẫn là cơ hội tốt để các nước tư bản xâu xé Trung Quốc. Là quốc gia từng ở đỉnh cao của văn minh thời cổ đại, đã giậm chân tại chỗ trong thời kỳ Trung cồ, đã rơi xuống đáy vực

\footnotetext{
12 Theo chuyên san The Economist (Anh), tại Nhật, khi phụ nữ có đứa con đầu tiên, $70 \%$ sẽ nghỉ việc trong khoảng 10 năm hoặc hơn (con số này tại Mỹ chỉ 30\%). Chính văn hóa doanh nghiệp, trật tự quan hệ xã hội Nhật Bản đã cản trở phụ nữ phát triển sự nghiệp của họ. Tại các công ty này, sự thăng tiến trong sự nghiệp thường dựa trên thời gian người nhân viên cống hiến cho công ty (thâm niên làm việc). Cũng theo The Economist, các ông chủ Nhật Bản thường ưu tiên chọn nam giới vào vị trí lãnh đạo, trong khi đó nhân viên nữ thường chỉ làm các công việc đơn giản và có mức lương thấp. Đây cũng là một trong những nguyên nhân khiến tỉ lệ kết hôn ở Nhật Bản đang ngày càng xuống thấp.

${ }^{13}$ Sự kiện này ở Trung Quốc trùng hợp với giai đoạn đầu của chế độ Mạc phủ Tokugawa (1600-1868): khi đó các tướng lĩnh cai trị đang tìm cách bảo vệ nhà nước Nhật và bản thân họ khỏi tầm ảnh hưởng của ngoại bang, trong đó có Trung Quốc. Với quyết tâm bảo vệ nền tự chủ đồng thời ý thức được các hệ tư tưởng trái chiều nhau, Mạc phủ đã ra lệnh cấm người dân Nhật Bản ra khỏi nước ngoài (người phạm tội sẽ bị xử tử). Các thương nhân Trung Quốc hầu như bị hạn chế sinh hoạt trong một khu phố người Trung Quốc trong thành phố Nagasaki.
} 
của sự sa sút trong thời kỳ cận đại, Trung Quốc trở thành "Người mê ngủ phương Đông", Đông phuoong thuy hám 東 方睡 闞, Đông phuoong thuy su 東方睡狮, Chư lão hổ 楮老虎,..bị các nước phương Tây khinh rẻ, gọi là hổ ngủ, hổ giấy ${ }^{14}$. Không chỉ đứng ngoài "cuộc khiêu vũ của thế giới” (C.Mác), Trung Quốc còn đứng trước nguy cơ bị "băm nát như quả dưa hấu" khi chỉ một số lượng ít ỏi các chiến hạm của nước Anh cũng đủ sức làm "bẽ mặt" nền văn minh vĩ đại của "Quốc gia trung tâm dưới gầm trời" trong cuộc Chiến tranh Nha phiến 鴉 片戰爭 (1839-1842). Cùng với sự lạc hậu của quan hệ sản xuất, ý thức hệ Nho giáo (ở trung tâm, chính quốc) cũng lâm vào trì trệ, trở nên lỗi thời và Khổng giáo trở thành "Ông già bảo thủ của phương Đông”. Trải qua hơn 20 thế kỉ hình thành và phát triển, Nho giáo ở Trung Quốc cũng có lúc thịnh lúc suy, có lúc ngự trên đỉnh cao của hệ tư tưởng thống trị nhưng cũng có lúc bị phê phán không thương tiếc và bị coi là thứ "rác bẩn" cần phải loại bỏ. Để tồn tại, Nho giáo cũng đã phải trải qua nhiều thăng trầm biến cố củ lịch sử ở chính quê hương của nó $^{15}$. Bàn về lễ giáo phong kiến, Fukuzawa Yukichi cho rằng: "Trong học thuật cũ của Trung Hoa không gì bằng lễ nhạc. Lễ் là để xui người ta cúi đầu phục tùng. Nhạc là để ru ngủ mọi nỗi bất bình uất ức của dân chúng để khiến cho người dân cứ mãi mãi thuận thụ dưới lũ hại dân"'[8, tr.123]. Nhật Bản và nhiều nước phương Đông đã nhận ra rằng "Tư tưởng (Nho

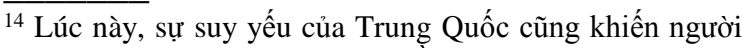
Nhật Bản coi thường: "Khi Y Đằng Bác Văn đi sứ Trung Quốc, ông ta ra câu đối cho Lý Hồng Chương 李 鸿 章: Nhật Bản Đông lai quang chiếu Đại Thanh toàn quốc日本 東来光照大清全 國”. Ở Việt Nam, tình hình cũng tương tự: câu đối của vua Đồng Khánh 同 慶 làm và được truyền tụng sau đây đã nói lên tình cảnh đương thời: $V \tilde{o}$ tuoóng tiêu sầu duy hĩu tưu/Văn thần thoái lỗ cánh vô thi 武將消愁惟有酒文臣退虜更無詩 (Quan võ chỉ biết uống rượu giải buồn. Văn thần càng không làm nổi bài thơ đánh giặc).

${ }^{15}$ Ngay trong thời hiện đại, tư tưởng bài Nho của Trung Quốc cũng không phải là không bị đặt ra. Nhưng dù bị phê phán, một số tư tưởng của Nho giáo vẫn tồn tại trong xã hội hiện nay.
}

giáo) đã mệt nhoài rồi, nó chẳng còn ích dụng gì nữa. Giống như một miếng giấy bạc, không còn thể nào vuốt thẳng ra được nữa khi đã bị vò nhàu" $[9$, tr.7].

Trong khi đó, "Từ thế kỉ XVI, tư tưởng và học vấn phương Tây đến Nhật Bản đã mở ra cách nhìn mới cho người Nhật về thế giới, về thiên nhiên và tạo ra một nền kỹ thuật mới ở quốc gia này. Trong thời kỳ cai trị của Mạc phủ Tokugawa, các học giả ở hệ thống trường Quốc học (kokugaku) đã nỗ lực làm sống lại tinh thần dân tộc và nới lỏng dần những ảnh hưởng của Trung Quốc. Khi nền học vấn tương đối phát triển thì việc học tập của người Nhật không chỉ tập trung vào Nho giáo mà còn quan tâm đến tri thức phương Tây qua các môn học khác. Từ cuối thế kỉ XVIII, Nhật Bản xuất hiện phong trào "Lan họ" (Rangaku) với mục đích học tập, tiếp thu khoa học kỹ thuật phương Tây bằng tiếng Hà Lan. Qua tiếng Hà Lan, họ đã dịch các sách về y học, văn học, kỹ thuật và những tài liệu dịch này có vai trò quan trọng giúp cho Nhật Bản tuy đóng cửa đất nước nhưng không bị tụt hậu quá xa so với các nước phát triển phương Tây đương thời. Cùng với phong trào học tập tri thức phương Tây ngày càng phát triển thì dư luận càng phê phán chính sách, chế độ đẳng cấp đã kìm hãm sự phát triển của cá nhân và xã hội" [10]. Nhờ Lan học và sau này là Tây phương học, với tinh thần cầu thị, người Nhật đã nhận ra rằng phải thay đổi chính sách nhương $D i$ (攘 夷 - chống phương Tây) bằng chính sách tích cực, linh hoạt, chủ động tiếp nhận thành tựu khoa học - kỹ thuật phương Tây. Theo thời gian, việc phổ biến văn hóa, kỹ thuật phương Tây được mở rộng sang hình thức bán công khai. Đồng thời "khi kiến thức của người Nhật Bản phát triển lên họ bắt đầu nhận ra rằng Trung Quốc không phải là trung tâm của thế giới, và họ cũng dần nhận ra những điểm yếu của Trung Quốc. Vì vậy mà họ nghĩ, "chúng ta nên bắt tay vào xác định vị trí của mình đi thôi" (Ian Buruma).

Theo David Pilling, sự cách ly khỏi Trung Quốc để định hình những giá trị Nhật Bản là một quyết định "đau đớn", bởi hầu như tất cả 
những giá trị văn hóa của họ đều bắt nguồn từ Trung Quốc. Tuy nhiên, xu hướng trên đây cũng bị tác động chi phối của bối cảnh chính trị nước Nhật trong giai đoạn cận đại. Sau 250 năm thống trị, đến giữa thế kỉ XIX chế độ Mạc phủ Tokugawa lâm vào khủng hoảng nghiêm trọng về mọi mặt. Về kinh tế, Nhật Bản vẫn là một nước nông nghiệp duy trì phương thức sản xuất lạc hậu dựa trên nền tảng phong kiến. Nông dân Nhật Bản phải chịu tô thuế nặng cộng với nạn mất mùa nên bị lâm vào cảnh đói kém, bần cùng. Trong khi nông nghiệp gặp nhiều khó khăn thì nhờ lợi thế hải cảng lớn, thương nghiệp ở Nhật lại bùng phát, thương nhân nhanh chóng phát giàu là cơ sở cho chủ nghĩa tư bản (CNTB) phát triển ở Nhật Bản. Về xã hội, Nhật Bản vẫn duy trì chế độ đẳng cấp với quyền bính do các đại danh (大 名/daimyo) và võ sĩ Samurai hoàn toàn nắm giữ ${ }^{16}$. Tầng lớp tư sản công thương nghiệp ngày càng giàu lên nhưng không có quyền lực chính trị, lại bị đánh thuế nặng nên tạo ra xung khắc ngày càng lớn giữa tầng lớp thương nhân và giai cấp thống trị. Người nông dân bị áp lực của cả giới quý tộc và thương nhân. Về chính trị, nền phong kiến Nhật Bản lẽ ra phải do vua Nhật (Thiên Hoàng) quyết định nhưng trên thực tế thì Mạc phủ Tokugawa thao túng hoàn toàn. Vì vậy, phe bảo hoàng tôn quân rất bất bình và khơi dậy phong trào lật đổ $M a c$ phủ 幕 府, trao lại quyền bính cho triều đình Thiên Hoàng. Về đối ngoại, các nước tư bản phương Tây nhân lúc tình hình Nhật Bản rối ren đã gây áp lực đòi Nhật Bản phải thông thương. Mạc phủ Tokugawa theo đuổi chính sách Tỏa Quốc bài duơng_(鎖 国 俳洋/Sakoku - nghĩa là "khóa đất nước lại" hay "khóa cửa biển lại" không cho người Tây phương ra vào), tuyệt đối không cho họ đặt chân đến Nhật. Trước thái độ cương quyết của Mạc phủ, năm 1853 Chính phủ Hoa Kỳ gửi bốn chiến thuyền Mississippi, Plymouth, Saratoga, và Susquehanna vào Vịnh Tokyo và trao tối hậu thư đe dọa sẽ nổ súng. Phó Đề đốc Matthew Calbraith Perry và

\footnotetext{
16 Tuy nhiên, thời kỳ này chiến tranh đã kết thúc, tình hình trong nước đã yên, nên địa vị của Samurai không còn như trước nên một số phải chuyển sang làm ruộng, làm thợ hay đi buôn.
}

"Những con tàu đen" đã chấm dứt chính sách ngăn cách thương mại với phương Tây của Mạc phủ Tokugawa (sự xuất hiện của phương Tây được cho là một sự thách thức với truyền thống và giá trị cổ truyền Nhật Bản). Sau một loạt hiệp ước bất bình đẳng với các nước đế quốc phương Tây và trước tình hình khủng hoảng dân tộc cũng như mâu thuẫn gay gắt trong ngoài, Nhật Bản đứng trước hai lựa chọn: $M o ̣ ̂ t$ là, giữ nguyên lề lối cổ truyền phong kiến và địa vị của Mạc phủ nhưng có nguy cơ mất nước vì bị ngoại bang đô hộ. Hai là mở một cuộc canh tân toàn diện nhằm học hỏi, tiếp thu kiến thức của phương Tây để chuyển mình thành một đất nước hùng mạnh, sánh vai với các cường quốc phương Tây. Trong bối cảnh thập niên 60 của thế kỉ XIX, phong trào đấu tranh chống Mạc phủ Tokugawa bùng nổ khắp nơi với sự lãnh đạo của các đại danh nổi dậy chống lại Chinh di Đại tuoóng quân (Sogun). Cuối cùng, chế độ Mạc phủ bị giải thể $(12 / 1867)$ và dưới khẩu hiệu tôn vuoong nhương di (尊 王 攘 夷/sonno joui) một số võ sĩ cấp tiến có đầu óc cải cách (phần lớn không có nguồn gốc thế tập) cùng với quý tộc ở triều đình đã nhân cơ hội nắm lấy quyền lãnh đạo đất nước và tiến hành các cải cách. Ngày $03 / 01 / 1868$, chính quyền mới do Thiên Hoàng Minh Trị bổ nhiệm được thành lập (Sự kiện này được gọi là vuoong chính phuc cồ 王政復古 - nghĩa là quyền vua trở lại như xưa). Giai cấp tư sản chưa được tham gia chính quyền nhưng chế độ mới tạo điều kiện cho CNTB phát triển nên họ ủng hộ chính quyền mới và thời kỳ Minh Trị - "sự cai trị sáng suốt" ở Nhật Bản bắt đầu.

\section{Minh Trị Duy Tân: tiến trình, nội dung co bản}

2.1. Minh Trị Duy tân (明 治 維 新/ Meijiishin/Meiji Restoration: 1868 -1912) còn gọi là Cải cách Minh Trị là một chuỗi các sự kiện cải cách, cách tân dẫn đến các thay đổi to lớn trong cấu trúc xã hội và chính trị của Nhật Bản ${ }^{17}$.

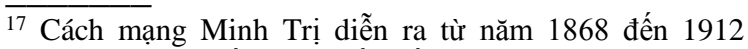
nhưng trên thực tế những tiền đề cải cách được diễn ra từ 1866-1869 (3 năm chuyển đổi của thời kỳ hậu Giang Hộ
} 
Người Nhật đã nêu đã nêu cao chủ trương Hòa thần Dương khí 和 神 陽 氣 (tinh thần Nhật Bản, tinh hoa phương Tây), khích lệ mọi người dân dốc sức học hỏi các nền văn minh mới. Từ một đất nước "đóng cửa" và chịu nhiều ràng buộc của các hủ tục lạc hậu, dân tộc Nhật trước hiểm họa xâm hấn của phương Tây, đã đứng lên cải cách trên nền tảng của đổi mới tư duy, thể hiện qua 5 lời thề thiêng liêng của Chính phủ (5 lời tuyên thệ của Thiên Hoàng Minh Trị khi lên ngôi) ${ }^{18}$ là: "Mở ra họi nghị rộng rãi, trăm công nghìn việc đều lấy theo công luận để quyết định"; "Trên dưới một lòng, ra súc sưa sang việc nước; Văn võ một đường, tù công khanh đến thư dân, đều được toại chí, khiến cho lòng người hăm hở sốt sắng; Thảy bỏ hết mọi thói hu, mối tệ chất chứa lâu đời, tù đây gắng gổ duy tân tụ cuòng, hiệp theo công đạo của trời đất; Cầu tri thức ở thế giới, làm cho nước nhà trở nên mạh lớn vé vang... Rồi thề sao làm vậy, 5 lời thề này chính là chí nguyện, quy mô và chính sách của vua Minh Trị sửa sang thay đổi nước Nhật, trước sau có chừng 30 năm, là trở nên một quốc gia văn minh, một dân tộc hùng cường, đứng ngang hàng với các nước Âu-Mỹ” [11, tr.70].

Cuộc cải cách đã đưa nền kinh tế Nhật Bản phát triển mạnh mẽ trong 30 năm cuối thế kỉ XIX, Nhật Bản trở thành một cường quốc quân sự vào năm 1905. Nhờ vậy, Nhật Bản đã phát triển đất nước theo con đường hiện đại hóa và tránh được sự xâm lược của các nước phương Tây vào thời Cận đại. Cải cách Minh Trị là sự kiện mang ý nghĩa bước ngoặt quan trọng trong lịch sử Nhật Bản mở đầu cho tiến trình hiện đại hoá và công nghiệp hóa kéo dài từ cuối thế kỉ XIX đầu thế kỉ XX, đưa Nhật Bản phong kiến từng bước trở thành một quốc gia độc lập, TBCN hiện đại, giàu có và hùng mạnh trong khu vực.

hay Hậu Tướng quân Tokugawa) và bắt đầu thời kỳ Minh Tri.

${ }^{18}$ Sau khi lên ngôi, ngày 7/4/1868, Minh Trị Thiên Hoàng cùng toàn bộ triều thần văn võ và các phiên chúa chư hầu (lúc này Nhật Bản còn tồn tại chế độ chư hầu, hai năm sau mới bị bãi bỏ) làm lễ nghiêm trang long trọng, tế cáo trời đất tổ tiên, đọc 5 lời thề thiêng liêng.
Thiên hoàng Minh Trị (3/11/1852$30 / 7 / 1912)^{19}$ sau quá trình lên ngôi và lật đổ chế độ Mạc phủ đầy sóng gió, dời đô từ Kinh đô(京都/Kyoto) về Đông kinh (東京/Tokyo tức thành Giang Hộ của Mạc phủ Đức Xuyên trước đây) và đặt niên hiệu mới. "Hoàng tử Mutsohito đã sớm nhận thấy thực trạng suy kiệt, bi đát của đất nước cũng như nhận thây nguy cơ của chủ nghĩa thực dân phương Tây đang ngày càng hiển hiện, đe dọa nền độc lập dân tộc. Trước tình hình đó, ông cùng với những người theo chủ nghĩa dân tộc cấp tiến quyết tâm đưa đất Nhật trở nên hùng mạnh. Biểu hiện đầu tiên của quyết tâm này là ngay sau khi lên ngôi, Mutsohito đã lấy niên hiệu là Minh Trị (明 治/Meiji - tức nền chính trị sáng suốt) [12]. Vị Hoàng đế- chủ soái của cuộc cải cách, người đặt nền móng cho sự "Thần kỳ Nhật Bản" đã tiến hành các cuộc cải cách đồng bộ và toàn diện trên tất cả các lĩnh vực của đời sống xã hội:

Về giáo duc, cải tổ nền giáo dục được đặc biệt quan tâm chú trọng. Nhiều cải cách quan trọng về giáo dục được thi hành trong đó có việc thành lập các trường Đại học để đào tạo tầng lớp lãnh đạo chính quyền và kinh doanh. Năm 1872 học chế được Bộ Giáo dục ban bố, bắt đầu một giai đoạn phát triển mới trong nền giáo dục Nhật Bản. Thi hành chế độ giáo dục cưỡng bức với việc mởra các hội truyền bá kiến thức học thuật, dịch thuật, văn hóa, khoa học, báo, thư viện. Đưa những thành tựu khoa họckỹ thuật vào giảng dạy và áp dụng chế độ giáo dục bắt buộc. Các môn học được chuyển chủ yếu từ học thuộc Kinh Sử sang Khoa học-Kỹ nghệ-Thương mại, áp dụng mô hình tự trị-tự chủ đại học theo hình mẫu phương Tây và cho phép tư nhân được mở trường học. Chất lượng dạy học cũng như chương trình chịu ảnh hưởng

\footnotetext{
${ }^{19}$ Thiên hoàng Minh Trị: tên thật (húy) là Mục Nhân (睦 仁/Mutxuhitô/Mutsuhitô) là vị Thiên Hoàng thứ 122 của Nhật Bản theo Danh sách Thiên Hoàng truyền thống, trị vì từ ngày $3 / 2 / 1867$ tới khi qua đời. Là vị Thiên hoàng trong thời kỳ Minh Trị, ông được biết với tên gọi Thiên Hoàng Minh Trị còn gọi là Minh Trị Đại Đế, Minh Trị Thánh Đế, Mutsuhito Đại Đế.
} 
Hoa Kỳ và phương Tây nhiều mặt ${ }^{20}$. Triều đình cũng cho du học sinh sang các nước phương Tây học về hệ thống chính trị, quân sự, kinh tế, tiếp thu khoa học kỹ thuật. Thiếu nhi từ 6-14 tuồi đều bắt buộc phải học tập và được triều đình chi trả $100 \%$ các khoản phí giáo dục với các môn học được áp dụng theo hình mẫu phương Tây. Với mong muốn đuổi kịp tri thức và tư tưởng phương Tây, "Văn minh khai hóa" (文 明 開 化/ bunmei kaika) dẫn truyền tinh thần và tri thức hiện đại hóa. Chỉ trong vòng 23 thế hệ, nước Nhật đã từ chỗ coi trọng thân phận con người theo nguồn gốc dòng dõi đã chuyển sang cất nhắc cán bộ theo trình độ giáo dục (tân học) và năng lực thực tế ${ }^{21}$. Hoàng đế Minh Trị cho rằng, công cuộc duy tân muốn thành công thì trước hết phải nâng cao trình độ hiểu biết của người dân để họ hiểu và tham gia tích cực vào sự phát triển của đất nước, đáp ứng được những đòi hỏi của tình hình mới. Bên cạnh những yếu tố tích cực của nền giáo dục truyền thống, ông kiên quyết loại bỏ những hạn chế và những sai lầm không đem lại lợi ích cho sự tiến bộ của nước Nhật. Chính sách coi trọng đào tạo nguồn nhân lực được đề xuất từ thời kỳ Minh Trị và được thể hiện rõ nét ở chú trọng phổ cập giáo dục phổ thông (đặc biệt là các cấp tiểu học được hình thành từ các trường học trong nhữngngôi chùa do các nhà sư dạy dồ). Kết quả của thực hiện chính sách này làkiến thức chung của người Nhật Bản đã được nâng cao, làm cơ sở cho giáo dục phổ thông trung học và đại học). Thời kỳ này Nhật Bản cũng diễn ra một chuỗi các sự kiện đổi mới như mở

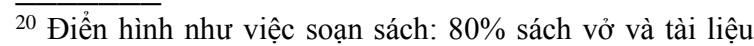
chuyên ngành được biên soạn theo mẫu phương Tây. Thời gian đầu Cải cách giáo dục, trong số 15 Đại học đầu tiên của Nhật có khoảng 500 giảng viên nước ngoài. Các giảng viên này được trả lương rất cao (300 Yên/ tháng so với lương công chức Nhật Bản lúc đólà 30Yên/tháng và hỗ trợ tốt về ăn ở, đi lại nhằm để họ cống hiến hết mình, truyền bá các kinh nghiệm của bản thân, giảng viên Nhật có thể học hỏi phương pháp của các GS nước ngoài. Những học sinh giỏi được cử sang du học ở nước ngoài.

${ }^{21}$ Điều này làm cho xã hội Nhật Bản trở nên bình đẳng một cách đáng kể (thậm chí hơn cả nước Anh cùng thời). Tuy nhiên, nó cũng làm cho tính giáo điều trở thành nếp trong suy nghĩ của người Nhật.
}

cửa toàn diện, kêu gọi Âu hóa, khuyến khích học tiếng Anh, chuyển sang dùng lịch Tây...

Về chính trị - xã hội, để tận dụng ưu thế trung tâm chính trị của Giang Hộ (Edo), triều đình Minh Trị đã đổi tên Giang Hộ thành Đông Kinh (Thủ đô ở phía Đông) và dời dô về đó. Nhằm khai thác tâm lí lo sợ Nhật Bản sẽ trở thành thuộc địa của phương Tây để khích lệ tinh thần canh tân, Người Nhật trở nên nhiệt tình với "văn minh và khai hóa" phương Tây. Triều đình còn đưa ra khẩu hiệu "phú quốc cường binh" và Thiên Hoàng tuyên bố từ bỏ những tập tục có hại và sẵn sàng học hỏi phương Tây. Cơ sở hạ tầng được quan tâm phát triển. Nhiều phái đoàn được cử sang phương Tây học hỏi về cách thức quản lí hành chính và kỹ thuật. Nhiều chuyên gia phương Tây được mời tới Nhật Bản để phổ biến kiến thức và kỹ thuật. Để xóa quyền lực của các đại danh, năm 1871 triều đình đã thực hiện phế phiên, lập huyện (藩 置 県/haihan-chiken) để xóa quyền lực của các đại danh, bãi bỏ hệ thống lãnh địa và danh hiệu của các đại danh. Đồng thời tuyên bố "tứ dân bình đẳng" (shimin byôdô) - nghĩa là bốn tầng lớp gồm võ sĩ, nông dân, thợ thủ công và thương nhân giờ đây không còn bị phân biệt ${ }^{22}$. Chính phủ được tổ chức theo kiểu châu Âu, tòa án mới được thành lập theo kiểu tư sản phương Tây. Triều đình cũng bỏ âm lịch theo lịch dương và bỏ y quan cũ theo mới. Năm 1889, Hiến pháp mói (大日本帝 國憲 法/Nippon Teikoku Kenpō?) được ban hành, quy định Nhật Bản là một quốc gia quân chủ lập hiến, thành lập Chúng nghị viện (衆 議 院 /Shugiin), mở đường của sự kết hợp truyền thống với hiện đại của văn hóa pháp luật Nhật Bản và đánh dấu sự ra đời của nhà nước Nhật Bản hiện đại. Thời kỳ Minh Trị Duy Tân, Nhật Bản là quốc gia đầu tiên của châu Á đã

\footnotetext{
22 Việc thực hiện "Tứ dân bình đẳng" gây bất bình ở tầng lớp võ sĩ, nên triều đình Minh Trị phải vừa đàn áp vừa xoa dịu bằng cách bồi thường bằng tiền. Khoản tiền nhận được từ triều đình cộng với tri thức mà tầng lớp võ sĩ được trang bị đã biến tầng lớp võ sĩ thành giai cấp tư sản. Giai cấp võ sĩ quý tộc tư sản chủ trương xây dựng Nhật Bản theo con đường quân sự là nguyên nhân dẫn đển việc Nhật Bản sau này trở thành đế quốc phong kiến quân phiệt.
} 
vận hành đất nước bằng hệ thống Hiến pháp. Cải cách Minh Trị Duy Tân là một biến đồi chính trị rất lớn đã kết thúc một giai đoạn lịch sử hơn 700 năm dưới sự thống trị của dòng họ võ sỹ tại Nhật Bản. Đây là kết quả của một quá trình đấu tranh, chuyển hóa xã hội diễn ra hết sức nhanh chóng trên quần đảo Nhật Bản với vai trò quan trọng của các võ sỹ có vị thế thấp trong việc xóa bỏ chế độ cầm quyền của chính tầng lớp võ sỹ (hệ thống phong kiến tản quyền tại các địa phương).

Về kinh tế, xóa bỏ chế độ độc quyền về ruộng đất của giai cấp phong kiến, thống nhất tiền tệ, phát triển kinh tế $\mathrm{TBCN}$ ở nông thôn, xây dựng cơ sở hạ tầng giao thông. Triều đình còn ban bố quyền tự do buôn bán (kể cả ruộng đất) và đi lại, thiết lập chế độ tiền tệ thống nhất (đồng Yên_円/えん/en-Yen ¥ -JPY), xây dựng cơ sở hạ tầng (nhất là đường sắt) và phát triển CNTB đến tận các vùng nông thôn (triều đình còn ra lệnh phế đao 废 刀 令 không cho người dân tự ý mang đao kiếm). Sự phát triển của kinh tế Nhật Bản đã làm xuất hiện các công ty độc quyền với các nhà tài phiệt thao túng nền kinh tế và chính trị Nhật Bản. Cải cách Minh Trị đã dẫn đến quá trình công nghiệp hóa, đưa nền kinh tế Nhật Bản phát triển mạnh mẽ trong 30 năm cuối của thế kỉ XIX và mở đường cho nước Nhật Bản phong kiến thành quốc gia hùng mạnhtrên thế giới.

Về quân sự, quân đội được tổ chức và huấn luyện theo kiểu phương Tây, như: lục quân theo mô hình lục quân Đức, hải quân theo mô hình hải quân Anh, các công xưởng và nhà máy vũ khí theo mô hình công binh Pháp, hệ thống hậu cần học thì hỏi rất nhiều từ Hoa Kỳ. Quân đội Nhật Bản áp dụng chế độ nghĩa vụ quân sự thay cho chế độ trưng binh, tăng cường mua và sản xuất vũ khí, đạn dược. Cùng với thành lập trường đại học lục quân chuyên về quân sự, Nhật Bản cũng chủ trương mời các giảng viên quân sự nước ngoài về để giảng dạy và đưa các sinh viên sĩ quan đến một số nước phương Tây (Anh, Pháp,...) học tập.

Về tôn giáo, Thần đạo thay thế cho Phật giáo trở thành Quốc đạo của Nhật Bản. Thần đạo mang tư tưởng chủ nghĩa yêu nước và tôn sùng Thiên Hoàng như một trong những vị thần.

Công cuộc Minh Trị duy tân (phá cũ đổi mới) trong 30 năm vừa mau chóng mạnh bạo, vừa vĩ đại hoàn toàn, như Minh Trị Thiên Hoàng đã thề với trời đất thần minh và dốc lòng thực hiện, từ chính trị văn hóa giáo dục, quân sự, công thương, lí tài, cơ khí, nghệ thuật, cho đến những chuyện y phục tầm thường, tập quán lặt vặt, chẳng sót môt vấn đề nào hay một phuơng diện nào mà không hóa xua theo nay, đổi cũ ra móit. Từ một quốc gia phong kiến lạc hậu, bên trong thì chia cắt bên ngoài thì bị các quốc gia khác chèn ép, sỉ nhục, chỉ trong ba thập kỉ, bao nhiêu dấu cũ lệ xưa của Nhật Bản đều bị xóa hết nhường chỗ cho văn minh mới phương Tây. "Sự thay cũ đổi mới của Nhật Bản mau lẹ quá chừng, ai cũng phải kinh hoàng sửng sốt. Mỗi việc nhỏ lớn gì cũng phải tạo lập ra mới mẻ hết thảy,... không có cơ quan chế độ nào hữu ích của phương Tây mà Nhật không làm theo. Xe lửa, tàu thủy, nhà băng, xưởng máy cùng là mọi việc giáo dục, công nghệ, khoa học... thứ nào Nhật Bản cũng tổ chức ra có đủ hết thảy trong một lúc" [11, tr.72]. Cuộc cải cách lớn do triều đình Thiên Hoàng thực hiện đã dẫn đến những thay đổi lớn lao đưa nước Nhật thoát khỏi chế độ phong kiến và sự lệ thuộc vào các nước phương Tây, tiến lên CNTB và trở thành Đại đế quốc duy nhất ở phương Đông đủ sức cạnh tranh với Nga, Anh, Hoa Kỳ, Đức - những cường quốc hàng đầu trên thế giới. Công cuộc cải cách toàn diện, cơ bản về mọi mặt do triều đình Minh Trị khởi xướng và lãnh đạo, có ý nghĩa mở đường đưa nước Nhật Bản phong kiến thành một nước TBCN, lần lượt chiến thắng Trung Quốc và Nga trong các cuộc Chiến tranh Giáp Ngo (Chiến tranh Nhật-Thanh 日 清戦 争/Nisshin Sensō, Jiawu: 1894 - 895) và đánh bại Hải quân Hoàng gia Nga năm 1905 (hai cuộc chiến tranh giúp Nhật Bản "thoát Á, nhập Âu"), trở thành một cường quốc quân sự ${ }^{23}$. Cải cách Minh Trị

\footnotetext{
${ }^{23}$ Cuộc cách cách Minh Trị ở Nhật Bản thành công, vì: (i) Người tiến hành cải cách là triều đình Minh Trị nắm trong
} 
được xem là thời kì quá độ từ chế độ phong kiến sang CNTB, đưa Nhật Bản phát triển theo mô hình các nước tư bản, thoát khỏi số phận một nước thuộc địa hay nửa thuộc địa ${ }^{24}$. Tuy nhiên, Minh Trị Duy Tân cũng được xem là cuộc cách mạng tư sản không triệt để bởi không do giai cấp tư sản lãnh đạo, không xóa bỏ hoàn toàn sự thống trị của giai cấp địa chủ phong kiến.

\section{Tư tưởng khai sáng - ngọn hải đăng dẫn đường cuộc cách mạng}

Thế giới được hướng dẫn bởi tu tuơong và cách mạng trong tu tương luôn là màn dạo đầu cho những biến đổi trong thực tiễn. Để tránh gặp phải số phận tương tự nhưTrung Quốc và các nước châu Á lúc đương thời, Nhật Bản đã tiếp nhận nền văn minh phương Tây và đoạn tuyệt với nguồn gốc châu Á của mình. Thành quả vĩ đại của cuộc Minh Trị Duy Tân được cộng hưởng từ nhiều yếu tố, trong đó không thể không kể đến vai trò của Fukuzawa Yukichi/Phúc Trạch Du Cát (福澤諭吉/ふく ざわゆきち ${ }^{25}$, một trong những nhà tư tưởng

tay quyền lực tuyệt đối và có tư tưởng duy tân tiến bộ; (ii) Được sự ủng hộ của các tầng lớp nhân dân, đặc biệt là tầng lớp Samurai; (iii) Trước khi tiến hành cải cách kinh tế TBCN tương đối phát triển mạnh ở Nhật Bản. Trong khi đó, cải cách ở Trung Quốc thất bại, vì: (i): Vấp phải sự chống đối mạnh mẽ của phái thủ cựu, đứng đầu là $T u H i$ Thái Hậu慈禧太后; (ii) Vua Quang Tụ 光 緒帝 chỉ là bù nhìn, không có quyền lực thực sự; (iii) Phong trào chỉ phát triển chủ yếu ở tầng lớp quan lại, sĩ phu có tư tưởng tiến bộ mà không được sự ủng hộ của đông đảo nhân dân; (iii) Kinh tế TBCN ở Trung Quốc kém phát triển hơn.

${ }^{24}$ Những sự kiện xảy ra ở Nhật Bản vào những năm 1860 - 1870 là một cuộc CMTS không triệt để và "thời kì Minh Trị" là thời kì quá độ từ chế độ phong kiến sang CNTB. Sau năm 1868, chính quyền không ở trong tay giai cấp tư sản mà là nền chuyên chế của Thiên hoàng, ra đời trên cơ sở liên minh quý tộc - tư sản để lật đổ chính quyền Mạc phủ. Các nhà lãnh đạo mới và tầng lớp ưu tú mới của đất nước đều có nguồn gốc võ sĩ, vì thế nước Nhật mới - Đại đế quốc Nhật Bản vẫn mang nhiều tính chất quân phiệt. Điều này giải thích tại sao Nhật Bản có nhiều hoạt động quân sự quy mô đến tận Chiến tranh thế giới lần thứ hai.

${ }^{25}$ Fukuzawa Yukichi (10/01/1834- 3/2/1901) là một trong những bậc khai quốc công thần và một nhà tư tưởng lớn lớn- -"bác sĩ bắt mạch chính trị" - chủ soái cuộc cải cách có công khai sáng phong trào canh tân để hình thành nên đất nước Nhật Bản hiện đại. Từ thực tiễn trải nghiệm phong phú của bản thân trong bối cảnh thời đại đầy biến động, sớm giác ngộ những giá trị và sức mạnh của văn minh phương Tây cùng với sự nhạy bén thời cuộc và ý thức sâu sắc trách nhiệm của người công dân, người trí thức chân chính đối với đất nước, Fukuzawa đã dành toàn bộ cuộc đời mình cho việc tìm kiếm những tư tưởng cải cách đất nước. Ông đã tập trung suy nghĩ, biện giải, tìm tòi cho ra đời học thuyết Thoát $\dot{A}$ Luận (脱 亜 論/isa訳/Good bye Asia- chủ trương thoát khỏi Châu Á) ${ }^{26}$ nổi tiếng làm nền tảng của công cuộc

có ảnh hưởng sâu và rộng nhất đến xã hội Nhật Bản cận đại. Ông là một nhà cải cách chính trị - xã hội, nhà giáo dục tiên phong, nhà tư tưởng tiêu biểu, nhà văn, nhà dịch thuật và là một võ sĩ của Nhật Bản từ cuối thời Edo, đầu thời kỳ Minh Trị - thời kỳ diễn ra những chuyển biến lớn lao trong lịch sử Nhật Bản; là người có công khai sáng phong trào canh tân nước Nhật, cồ động dân chúng trút bỏ tư duy lạc hậu thời cổ đại mà tiếp thu học thuật Tây phương hầu sánh bước với các nước Âu Mỹ. Tư tưởng mà ông truyền bá có ảnh hưởng rất lớn tới phong trào Khai sáng ở Nhật Bản vào cuối thế kỉ XIX và đầu thế kỉ XX, đã thay đổi hoàn toàn diện mạo của đất nước Nhật Bản vào cuối TK XIX và tạo tiền đề cho Nhật Bản trở thành một cường quốc trên thế giới. Tài năng và nhân cách Fukuzawa Yukichi thăng hoa cùng với những năm tháng của cuộc cải cách Minh Trị duy tân. Ông đã để lại trước tác với số lượng lên tới hàng vạn trang, trong đó tiêu biểu phải kể đển là Gakumon no susume (Khuyến học), Bunmeiron no gairyaku, (Khái lược Văn minh luận (1875), Seiyō jijōo (Tây Dương sự tình), Fukuō Jiden (Phúc ông tự truyện)... Nếu "Khuyến học" của Fukuzawa vạch ra hành trình phát triển cho một con người, một cá nhân thì "Khái lược văn minh luận" là dành cho một dân tộc, một quốc gia. Là cuốn sách được viết ra để trực tiếp giải quyết những vấn đề, những tranh luận của thời kỳ đó, nhưng hàm ý của nó vẫn có giá trị đến hôm nay. Người phương Tây sánh ông như "Voltaire của đất nước mặt trời mọc", là "Võ sĩ vĩ đại nhất mà Nhật Bản từng có". Lòng biết ơn của người Nhật đối với Fukuzawa được thể hiện qua việc hình ông được in trên tờ tiền 10.000 Yen (tờ giấy bạc có mệnh giá lớn nhất của Nhật), dù ông không phải thuộc hạng vua chúa hay võ tướng lồi lạc của đất nước Nhật Bản.

${ }^{26}$ Mục đích của chủ trương Thoát Á là giữ độc lập cho nước Nhật và giúp nước này phát triển theo kịp các nước phương Tây đương thời. Tuy nhiên, cũng có ý kiến cho rằng, mặt trái của Toát Á luận là góp phần hình thành tư tưởng bài Á, sô vanh - khởi nguồn của chủ nghĩa quân phiệt Nhật Bản sau này. 
Minh Trị Duy Tân, đưa nuoớc Nhật thoát khỏi nguy co lệ thuộc và phát triển sánh vai với các cuờng quốc phuoong Tây, trở thành đỉnh cao trí tuệ của phong trào cải cách và là cánh chim én đón Xuân của xứ sở Hoa Anh đào (Người phương Tây coi ông như "Voltaire của đất nước Mặt Trời mọc").

Nội dung chính của bài "Thoát Á luận" nổi tiếng này (cũng là chủ trương của Fukuzawa Yukichi) được tóm gọn trong hai chũ̃ "Thoát Á" - Nghĩa là thoát khỏi vòng kiềm tỏa của nền văn hóa tiểu nông, cổ hủ lạc hậu, nặng về hình thức giả tạo bên ngoài của các nước châu Á (điển hình là Trung Quốc) để học theo nền văn minh phuoong Tây và hội nhập với thế giới bên ngoài. Theo đó, nuớc Nhật tù bỏ những cản trở có nguồn gốc tù truyền thống Á châu trên con duờng tuoong lai của minh. Theo Fukuzawa, không thể để Nhật Bản bị nền phong kiến Trung Hoa và Hàn Quốc làm cho trì trệ, và nên "thoát khỏi vòng tư tưởng của các quốc gia châu Á mà gia nhập với các quốc gia văn minh phương Tây (thoát Á nhập Âu). Bài luận nổi tiếng này đã khơi nguồn cho dòng tu tưởng Khai sáng ${ }^{27}$ của Nhật Bản và trở thành nền tảng tinh thần của cuộc Cải cách Minh Trị. Nhờ chủ trương này, cùng với sự triển khai thành công của phong trào Duy Tân, Nhật Bản đã hình thành được một hệ thống các thang giá trị mới và hội nhập được với bên ngoài, giúp cho nước Nhật không chỉ giữ được độc lập mà còn trở thành một cường quốc về kinh tế, văn hóa và khoa học kỹ thuật sau này.

Được tiếp xúc với văn minh phương Tây qua sách vở và những chuyến viếng thăm Mỹ

\footnotetext{
27 Immanuel Kant (1724 - 1804), triết gia lớn nhất của nước Đức và của thời cận đại (Neuzeit) cho rằng: "Khai sáng là sụ thoát ly của con ngườ ra khỏi tình trang vi thành niên do chính con người gây ra. Vi thành niên là sự bất lực không thể vận dụng trí tuệ của mình một cách độc lập mà không cần sự chỉ đạo của người khác. Tình trạng vị thành niên này là do tụ mình gây $r a$, một khi nguyên nhân của nó không phải do sự thiếu sót trí tuệ, mà do sự thiếu sót tính cương quyết và lòng can đảm, dám tự mình dùng trí tuệ phục vụ cho mình mà không cần đến sự chỉ đạo của người khác. Sapere aude! Hãy có can đảm tự sử dụng trí tuệ của chính mình!" là phương châm của Khai Sáng.
}

và châu Âu vào cuối thế kỉ XIX, Fukuzawa nhận thức được tiến bộ của văn minh phương Tây (những nước phát triển hơn châu Á về nhiều mặt) và các nước châu Á khó có thể duy trì được nền độc lập nếu vẫn đóng cửa trước văn minh phương Tây. Theo ông, giành được quyền tự trị chưa phải đã là độc lập, mà nền độc lập thật sự chỉ có thể thành hiện thực khi trở thành một quốc gia tiên tiến và văn minh. Và nếu không có sự khai sáng và văn minh thì nền độc lập giành được cũng mau chóng mất đi và lại lệ thuộc vào các quốc gia tiên tiến khác. Nhận thức được tình trạng các nước trong khu vực châu Á mới chỉ ở mức "bán văn minh", không thể là tấm gương cho Nhật Bản học hỏi, vì vậy Fukuzawa kêu gọi nước Nhật hãy "tách ra khỏi hàng ngũ các nước châu Á, đuổi kịp và đứng vào hàng ngũ các nước văn minh phương Tây" [13]. Ông chủ trương mở cửa giao thương với phương Tây, học hỏi kiến thức và kinh nghiệm quản lí xã hội của phương Tây để phát triển Nhật Bản ${ }^{28}$. Fukuzawa tin rằng giáo dục là cách duy nhất để đạt tới văn minh, bởi bản chất của văn minh là sự phát triển kiến thức và đạo đức nội tại của dân tộc: "phải có đầy đủ cả về phương diện vật chất lẫn tinh thần thì mới có thể gọi là văn minh. Tuy nhiên, sụ tiện nghi về mặt vật chất cũng nhu sư cao thuợng của tinh thần con người thì không hề có giới hạn. Vì vậy gọi là "tiện nghi" hay "cao thuợng" thì phải nghĩ đó là nói đến trạng thái tiến bộ để huớng tới một trình độ cao hơn. Và bởi vì tri thức và đạo đức là động lực của sư tiến bộ này, nên kết cục có thể nói văn minh chính là sư tiến bộ của tri thíc và đạo đức của con người" [14, tr.95$96]^{29}$.

\footnotetext{
${ }^{28}$ Quan điểm này của Fukuzawa đã được chứng minh bằng thực tế: Ở châu Á, chỉ có Nhật Bản và Thái Lan - hai nước chủ trương mở cửa tránh được sự xâm lược và thôn tính của các nước phương Tây.

${ }^{29}$ Nguyên văn "In its broad sense, civilization of virtue so as to elevate human life to a higher plane. [...] [Thus] it refers to the attainment of both materia well-being and the elevation of the human spirit, [but] since what produces man's well-being and refinement is knowledge and virtue, civilization ultimately means the progress of man's knowledge and virtue" - Fukuzawa Yukichi - written by
} 
Theo Fukuzawa, nền giáo dục Nho hoc (Kangaku) truyền thống ở Nhật Bản là sự cản trở lớn nhất của nền văn minh: nó vừa cổ hủ vừa chậm phát triển, hàng nghìn năm vẫn không thay đổi, chỉ coi trọng hình thức bên ngoài giả tạo mà coi thường chân lí và nguyên tắc. Số lượng người đi học đã ít ỏi, lại chỉ được dạy đọc/viết mà không được khuyến khích phát triển tư duy sáng tạo và độc lập (phê phán kịch liệt lối học từ chương, trích cú trước đây). Fukuzawa cho rằng, giáo dục là chìa khóa của văn minh, cốt lõi của giáo dục là thực học và tính hiệu quả của nền giáo dục cần đáp ứng yêu cầu của mọi tầng lớp khác nhau trong xã hội. Mục tiêu quan trọng của giáo dục là hình thành nhân cách độc lập, bởi vì "Nền văn minh của quốc gia không thể trông cậy vào quyền lực của chính phủ mà phải quan tâm đến từng người dân. Mỗi người dân phải có trách nhiệm với việc bảo vệ, gìn giữ nền độc lập của đất nước" $[15$, tr.13]. Ông cũng đưa ra nguyên tắc nổi tiếng "Độc lập quốc gia thông qua độc lập cá nhân" (National independence through personal independence), tức là một xã hội muốn phát triển phải dựa trên những cá nhân có khả năng tư duy độc lập và sáng tạo (individual strength tự tin vào sức mạnh cá nhân), chứ không phải dựa vào chính phü ${ }^{30}$. Nguyên tắc cơ bản của giáo dục là phải kết hợp khoa học phương Tây với đạo đức phương Đông. Ông kêu gọi các sĩ phu Nhật Bản làm việc theo phương châm "Coi trọng quốc gia và coi nhẹ chính phủ” [13], tự tin vào sức mạnh cá nhân mà không phụ thuộc

\footnotetext{
Nishikawa Shunsaku, Fukuzawe.pdf-Foxit Reader [Fukuzawe.pdf].

${ }^{30}$ Nguyên văn: "Quốc dân Nhật Bản chúng ta phải xắn tay ngay vào học tập, hun đúc chí khí. Trước hết mỗi cá nhân, từng con người hãy kiên quyết tự chủ, độc lập. Có như vậy, đất nước mới giàu mạnh. Có như vậy chúng ta mới hết mặc cảm, hết sợ hãi trước các thế lực phương Tây... Mỗi người độc lập thì đất nước sẽ tự chủ, độc lập, nghĩa là vậy" (Fukuzawa Yukichi, Khuyến học hay những bài học về tinh thần độc lập tự cường của người Nhật Bản, $\mathrm{Nxb}$ Iwanami Bunko Tri thức và phát triển, $\mathrm{Nxb}$ Trẻ (Phạm Hữu Lợi dịch).

https://sachvui.com/sachvui-

686868666888/ebooks/2018/pdf/Sachvui.Com-khuyenhoc-fukuzawa-yukichi.pdf.
}

vào sức mạnh của người khác. Mỗi người trong xã hội, từ các học giả uyên bác, những viên chức nhà nước địa vị cao đến những nông dân nghèo và những người buôn bán nhỏ đều có thể đi học để thực hiện tốt hơn chức năng riêng của mình, từ đó đóng góp sức mình vào phát triển xã hội, chứ không nhất thiết phải học để ra làm quan theo lối suy nghĩ truyền thống của Nho học hủ lậu (tư tưởng Khai sáng của Immanuel Kant). Người dân hãy theo đuổi nền giáo dục thực học của phương Tây, dựa trên nền tảng khoa học và kỹ thuật.

Phê phán nền giáo dục Nho học chú trọng cổ văn nhưng coi thường kiến thức thực tế của Trung Hoa và Triều Tiên, Fukuzawa Yukichi cho rằng 2 nước này "suốt hàng nghìn năm không hề thay đổi và vẫn quyến luyến với những phong tục tập quán cũ kĩ, khi bàn luận về giáo dục thì lên tiếng giữ gìn nền giáo dục Nho học, chỉ biết trích dẫn những lời giáo huấn "Nhân, Nghĩa, Lễ, Trí", chỉ coi trọng hình thức bên ngoài giả tạo mà coi thường chân lí và nguyên tắc, mê tín hủ lậu không biết khoa học là gì lại còn kiêu căng tự phụ"[13] ${ }^{31}$. Với con mắt đại bàng, Fukuzawa Yukichi nhận thấy: "Đường giao thông trên thế giới là phương tiện để làn gió của văn minh phương Tây thổi vào phương Đông. Khắp mọi nơi, không có cỏ cây nào có thể ngăn được làn gió văn minh này"[13]. Ông đã nhìn ra cái không gian bí bách, "cổ lai hi" và đáng "xấu hổ" của Á châu mà cổ vũ người Nhật thực thi tư tưởng thoát Á.

Sớm thức tỉnh trước nguy cơ mang tính thời đại để nhanh chóng tiếp nhận nền văn hóa phương Tây với tính ưu việt của nó trên các

\footnotetext{
${ }^{31}$ Tuy nhiên, việc đả kích Nho học ở Nhật Bản thời kỳ này cũng có hạn chế: do bắt đầu từ cái nhìn "sùng bái một chiều về nền văn minh vật chất phương Tây cũng như phủ nhận một chiều những giá trị thực sự của dân tộc mình", đi tới nguy cơ đánh mất chính mình trong công cuộc "văn minh Âu hóa" đầy rẫy bi kịch. Ánh hào quang của các tiêu chí phương Tây tuy có nhiều giá trị gợi mở nhưng cũng không ít hiểm họa mà đáng sợ nhất là tinh thần sùng bái vật chất, lối sống nhân danh "đấu tranh sinh tồn", "chủ nghĩa tinh hoa", "chủ nghĩa dân tộc cực đoan”,...vốn có quan hệ khá nhiều với các chính sách xâm lược thực dân, chế độ phát xít.
} 
lĩnh vực công nghiệp, khoa học kỹ thuật, sự hùng cường về cả kinh tế và quân sự; cuộc cải cách Minh Trị Duy Tân mặc dù cách đây 150 năm nhưng vẫn được các học giả trong và ngoài Nhật Bản nhắc đến như một mốc son đưa quốc gia này trở thành cường quốc ngang hàng với các nước tư bản Âu - Mỹ cuối thế kỉ XIX. Cuộc cải cách toàn diện này đã tạo ra những tiền đề thuận lợi cho sự giải phóng những tiềm năng khổng lồ của đất nước "Mặt trời mọc". Bản chất của 30 năm Duy tân Minh Trị là quá trình dân tộc Nhật Bản nhìn văn minh châu Âu để tự khai sáng tinh thần cho chính mình. Từ bài học thức tỉnh về "Thoát Á luận", Nhật Bản đã "thoát Á" thành công khi biết phát huy tinh thần quả cảm, dám xả thân của các võ sĩ đạo, biết giữ lấy những giá trị đạo đức thuần túy "Nhân, Nghĩa, Lễ, Trí, Tín" của Khổng giáo trong khi loại bỏ phần chính trị và các thiết chế bắt nguồn từ đó, nhất là hệ thống thi cử từ chương đã đè nặng trong lịch sử. Cuộc cải cách đã thu được thành công và tiếng vang lớn, tạo cơ sở vững chắc giúp Nhật Bản phát triển xứng tầm một nước văn minh, hiện đại, có nền kinh tế phát triển hàng đầu thế giới.

Cuộc cách mạng trong tư tưởng luôn là màn dạo đầu của cuộc cách mạng trong thưc tiễn. Đối với Nhật Bản, cách ly/cắt đứt mối liên hệ về mặt tư duy với Trung Quốc và chuyên tâm vào nỗ lực hiện đại hóa đất nước, hội nhập với phương Tây là một quyết định dũng cảm và đầy lí trí. Người Nhật đã ý thức được rằng: Điều quan trọng nhất là phải thoát khỏi cái văn hóa của Trung Quốc tức là văn hóa Khổng giáo. Cái văn hóa đó nó tha hóa nguoòi trí thức, nó không nhìn nhận sư suy nghĩ và hành động độc lập của cá nhân như là một giá trị. Trái lại nó coi cái chĩ "trung" (trung thành) với nhà cầm quyền nhu một giá trị co bản". Trên nền của tư duy lí, người Nhật Bản đã sớm nhận thức được rằng: suy cho cùng, phát triển chỉ đạt được từ đổi mới và sáng tạo. Và những cản trở đáng kể nhất cho sự đổi mới và sáng tạo là những cản trở nội tại, nằm ngay trong chính bản thân mình để giải phóng năng lực mọi mặt của đất nước cho phát triển, đương đầu và thích nghi được với một thế giới đầy biến động và thay đổi không ngừng. Và quan trọng hơn: không sa vào những bẫy vô hình, do sự vô tình hay cố ý của con người hoặc ngẫu nhiên của lịch sử tạo ra. Với tư duy đi trước thời đại, người Nhật cũng tỉnh táo nhận ra rằng: "Thoát Á" hay "thoát Trung" nghĩa là thoát cái quê mùa lạc hậu, hạn chế của các nước châu Á nhưng vẫn giữ lại cái gốc tinh hoa của mình trong văn hóa Khổng giáo; du nhập khoa học kỹ thuật của Tây phương nhưng vẫn giữ bản sắc của Nhật Bản. Triều đình và những trí thức Nhật Bản, một mặt đã nhận thức được những hạn chế của nền giáo dục Nho giáo trong thời kỳ mới, mặt khác họ vẫn thấy được giá trị của Nho giáo trong việc giáo dục đạo đức, nhất là giáo dục lòng trung thành, xây dựng đất nước Nhật Bản theo chủ trương "nước giàu binh mạnh". Trong bối cảnh của nước Nhật thế kỉ XIX, những tư tưởng cải cách của Fukuzawa Yukichi hết sức sâu sắc, thiết thực, đáp ứng yêu cầu cấp bách của thực tiễn lịch sử Nhật Bản lúc đương thời và đóng vai trò quan trọng, tạo tiền đề tư tưởng cho công cuộc Duy Tân Minh Trị. Thoát Á luận của Yukichi trở thành tác phẩm làm thay đổi lịch sử nước Nhật, thay đổi tư duy của cả môt dân tộc để xây dựng nuớc Nhật hiện đại và cho thấy sự manh mẽ, vĩ đại của một dân tộc đã dũng cảm không chịu đầu hàng số phận và dám đối mặt với nhũng thách thức của lịch sư để vươn lên hàng đầu thế giới. Kinh nghiệm lịch sử cũng cho thấy: trước mỗi giai đoạn có tính bước ngoặt, lịch sử luôn đặt ra cho mỗi quốc gia-dân tộc những nhiệm vụ chiến lược và thách thức to lớn; đòi hỏi sự quyết tâm, ý chí, sự chung sức đồng lòng (thậm chí là sự hy sinh) của cả một dân tộc để vượt qua và tiếp tục đi lên. Để đưa công cuộc Cải cách Minh Trị thành công, người Nhật đã sớm thức tỉnh yêu cầu phải vượt qua những tư tưởng nhận thức lạc hậu để đón nhận những tư tưởng mới, tiến bộ, hiện đại và tư duy phát triển để đưa đất nước thoát khỏi nghèo nàn, tụt hậu và thông qua những chính sách cải cách tiến bộ để giải phóng năng lực mọi mặt của đất nước. Vấn đề đổi mới tư duy 
nhận thức về hội nhập và phát triển được người Nhật xác định là khâu đột phá, có ý nghĩa mở đường cho những biến đổi xã hội mạnh mẽ thời kỳ Minh Trị. Đồng thời, tư tường cải cách, tiếp thu văn minh nhân loại đi đôi với giữ gìn, phát huy giá trị tinh hoa của dân tộc; kết hợp tinh hoa nội ngoại để xây dựng, phát triển đất nước của Nhật Bản vẫn là bài học cho các quốc gia trên con đường hiện đại hóa, xây dựng phát triển đất nước hôm nay.

\section{Tài liệu tham khảo}

[1] Lý Minh Tuấn, Tứ thư bình giải, NXB Tôn giáo, 2011.

[2] Vũ Dương Ninh, Nguyễn Văn Kim, "Một số chuyên đề lịch sử thế giới”, tập 2, NXB. Đại học Quốc gia, Hà Nội, 2008.

[3] Fukuzawa Yukichi, Phúc Ông tự truyện (Phạm Thu Giang dịch), NXB.Thế giới, 2017.

[4] George.B.Sansom, Lược sử văn hóa Nhật Bản, tập 2, NXB. Khoa học xã hội, Hà Nội, 1989.

[5] Trung Quốc cận đại giản sử, NXB. Nhân dân Thượng Hải, 1975.

[6] Phan Đại Liên, Lịch sử Nhật Bản, NXB. Văn hóa Thông tin, Hà Nội, 1995.
[7] Fukuzawa Yukichi, (Phạm Hữu Lợi dịch), "Khuyến học" hay những bài học về tinh thần độc lập tự cường của người Nhật Bản, Nxb Iwanami Bunko Tri thức và phát triển, NXB Trẻ, 2017.

[8] Vũ Khiêu, Nho giáo và phát triển ở Việt Nam, NXB. Khoa học xã hội, Hà Nội, 1997.

[9] Francois Jullien, (Nguyên Ngọc dịch), Minh triết phương Đông và Triết học phương Tây hay thể tạng khác của Triết học, editions du Seuil, Février, 1998.

[10] Nguyễn Thị Hồng Vân, Cơ cấu xã hội Nhật Bản thời Cận thế, Tạp chí Nghiên cứu Đông Bắc Á, số 4/2009.

[11] Đào Trinh Nhất, Nhật Bản Duy Tân 30 năm, Đông Phương xuất bản, Sài Gòn, 1936.

[12] Liên hiệp Các Hội KH\&KT Việt Nam, Tạp chí Nhà quản lí, 27(9)/2005.

[13] Fukuzawa Yukichi, (Hải Âu, Kuriki Seiichi dịch) “Thoát Á luận”, 1885.

http://www.chungta.com/nd/tu-lieu-tra cuu/thoat_a_luan.html

[14] Fukuzawa Yukichi, Lê Huy Vũ Nam, Nguyễn Anh Phong dịch), Bàn về văn minh (First published in 1875; NXB. Thế giới, 2018.

[15] Fukuzawa Yukichi, (Phạm Hữu Lợi dịch), Khuyến $h o c$ hay những bài học về tinh thần độc lập tự cường của người Nhật Bản, NXB. Iwanami Bunko Tri thức và phát triển, NXB. Trẻ, 2017. 